\title{
KEKPS・ブースターにおける加熱脱ガスをしない 排気系の検討*
}

\author{
成島 勝也 ${ }^{* *}$. 久保 富夫**. 佐藤 吉博 ${ }^{* *}$
}

（受付1990年11月 30 日，揭載決定1991年 3 月 2 日）

The Study of Non-Bakable Vacuum System for KEK PS-Booster Ring

Katsuya NARUSHIMA, Tomio KUBO and Yoshihiro SATO

(National Laboratory for high Energy Physics, Tsukuba, Ibaraki, 305)

(Received november 30, 1990, Accepted March 2, 1991)

\section{1. はじめに}

KEK（高エネルギー物理学研究所）のPS（陽子シン クロトロン）では, 設計時の目標圧力が $10^{-6}$ Torr 程 度1であるため, 真空系全体が加熱脱ガスを考慮された 系となっていない.このため真空内に設置する装置を設 計する際, 使用材料のガス放出率, 耐熱性, 耐放射線等 のパラメーターを充分に考慮せずに製作してしまらこと が，長年月の間に不自然でなく習慣となりがちである. 運転開始直後の時点では真空以外での種々の改良等を迅 速に行なわねばならないために，上記のことは，ある程 度は必要であるが, 建設時の目的をほぼ達した後, マシ ンの改良を計画する際にマイナスの条件となっている。 またイオンポンプを正常な起動状態にするために非常に 多くの粗排気時間と労力を消費することにもなってい る. 本報告では KEK-PS 特にブースター真空系におけ る粗排気系, 及びイオンポンプの起動特性を例として加 熱脱ガスをしない系の一般的な考え方について述べる.

\section{KEK・PS・ブースター真空系}

Fig. 1 に示すよらに 6 台の $1000 \mathrm{l} / \mathrm{s}$ のイオンポンプが 各チェンバーにバルブを介することなく直結されてい る. 粗排気用ポンプとして $300 \mathrm{l} / \mathrm{s}$ のターボ分子ポンプ が $\mathrm{S}_{1}, \mathrm{~S}_{2}, \mathrm{~S}_{5}$ に配置されている。通常，イオンポンプ

\footnotetext{
* 平成 2 年10月 25 日 第 31 回真空に関する連合講演会で発表 (25P-35)
}

**高エネルギー物理学研究所 (茨城県つくば市大穗 1 の 1)
は，起動の際に大量のガスを放出し，正常動作が困難と なることがあるため, 一般には外部ヒーターによって加 熱脱ガスを行ならが，ここではセルフベーキング方式を 採っている（セルフベーキングとはイオンポンプ起動初 期の放電による加熱脱ガス). ただしイオンポンプの無 理な起動をさけるため $\mathrm{P} \leq \mathrm{P}_{1}\left(\simeq 3 \times 10^{-4}\right.$ Torr $)$ で電源 $\mathrm{ON}, \mathrm{P} \geq \mathrm{P}_{2}\left(\simeq 1 \times 10^{-3}\right.$ Torr $)$ で電源 $\mathrm{OFF}$ となるよう なコントロールを行ない, ポンプを定常運転に導いてい

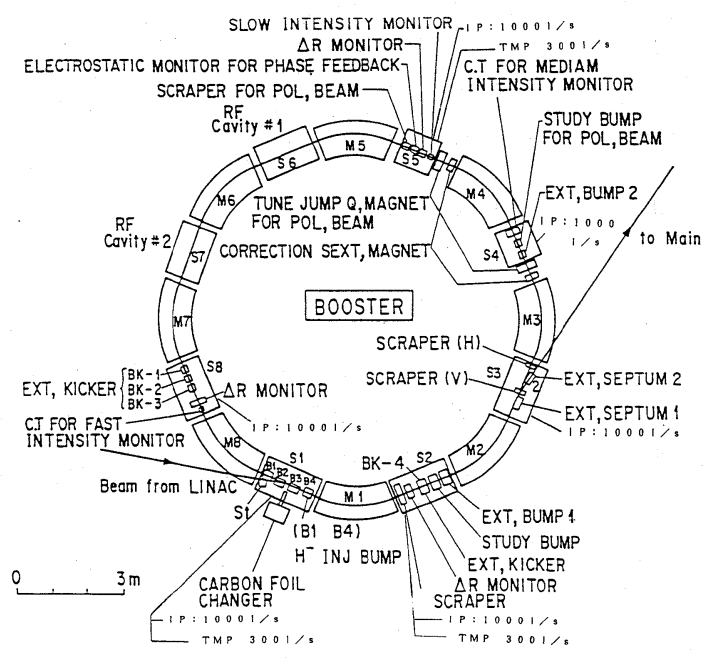

Fig. 1 KEK-PS BOOSTER 


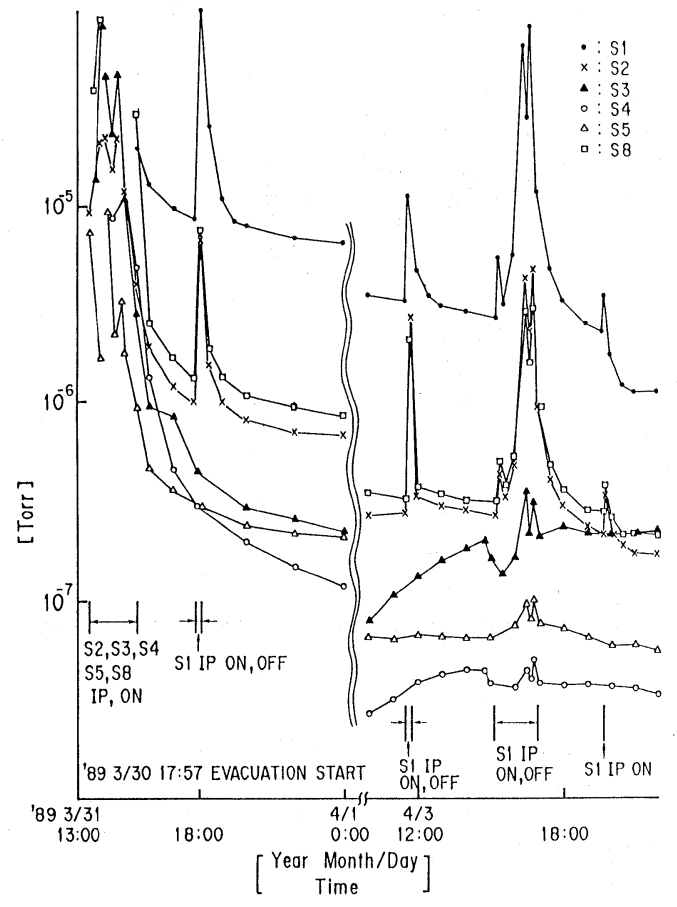

Fig. 2 Typical pumping down curves of the KEKPS BOOSTER.

く方式をとっている. したがって粗排気系は, 少なくと も $3 \times 10^{-4}$ Torr 以下に排気する能力が要求される。 し かし全周約 $36 \mathrm{~m}$ にわたる細いベローズドーナッ管を 3 個所の粗排気系から排気するだけでは，小さい導管ュン ダクタンスと壁面よりのガス放出から，これは非常に困 難である。また，ブースタ一真空系では，ビームの入 射, 取出し用の電磁石, 及びそれらを設置する大型の真 空チェンバーが多く, ガス放出量の非常に多い真空系で ある. そこで先ず, 粗排気系に最も近いポンプを起動さ せ，順次その次のポンプの動作へと波及させていくカス ケード方式を採用している．ガス負荷の一番大きな $\mathrm{S}_{1}$ では, Fig. 2 に示すよらに, イオンポンプの電源を何回 も ON-OFFをくり返し約 3 日目に起動が完了してい る. $\mathrm{S}_{2} \sim \mathrm{S}_{8}$ は $5 \sim 6$ 時間で起動は完了している. 乾燥窒 素で一気圧にもどして約 5 時間程度の作業の後に再排気 した場合でも, 再起動完了となるには, 平均しても2 3 日を必要とする.この $2 \sim 3$ 日の間の労力と時間は問 題である．これがブースタービームの再立上げに要する 時間を決定するからである。

\section{3. イオンポンプ起動時間の改善}

$\mathrm{S}_{1}$ のイオンポンプヘッドにゲートバルブを設置し,

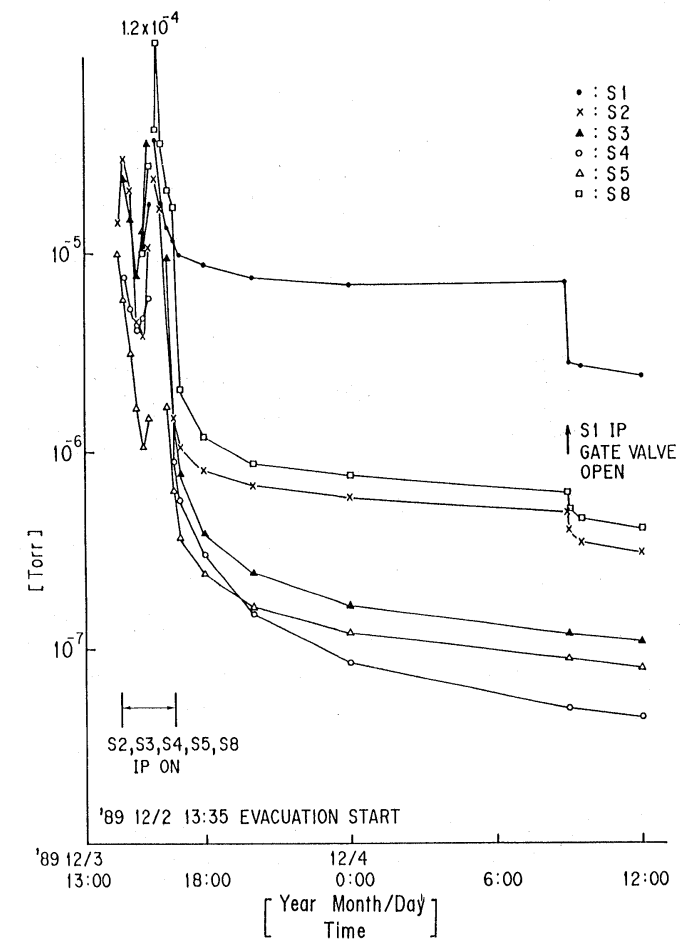

Fig. 3 Effect of S1 gate valve on pumping down time of the KEK-PS BOOSTER.

メンテナンスの際にバルブを閉じてイオンポンプを一気 圧にしないで高真空に維持しておいたまま，次に系を再 排気した時のデータをFig. 3 に示す。図では約20時間 後にバルブを開けて，そのままイオンポンプの運転が継 続できたことを示している.さらに $\mathrm{S}_{2} \sim \mathrm{S}_{8}$ が起動完了 となる5〜6時間の時にバルブを開けても $\mathrm{S}_{1}$ は運転継続 ができたであろらと考えられる。このことから，イオン ポンプを一気圧に曝さずに系の粗排気を充分に行なった 後イオンポンプに取付けたゲートバルブを開ければ，系 の再立上げに要する時間は短縮することが期待される.

\section{4. ブースターリングの圧力}

1989年12月〜 3 月におけるブースターリングの運転時 の圧力分布をFig. 4 亿示す．粗排気を開始してから約 1 力月後にビームのない状態（各種電磁石が OFF の状 態）で $\mathrm{S}_{1}$ で $10^{-7}$ Torr 領域に入りほぼ平衡圧力を示し た. $\mathrm{S}_{4}$ は $10^{-9}$ Torr 領域に入りつつある. ビーム ON で $\mathrm{S}_{1}$ は約 $1.5 \times 10^{-6}$ Torr を示している. 他の $\mathrm{S}_{2} \sim \mathrm{S}_{8}$ は 1 桁〜 2 桁下の圧力を示している. したがって今後ブース ター圧力を改善するには真空中に設置されている各種電 磁石を加熱脱ガスが可能なものに設計変更するか，また 


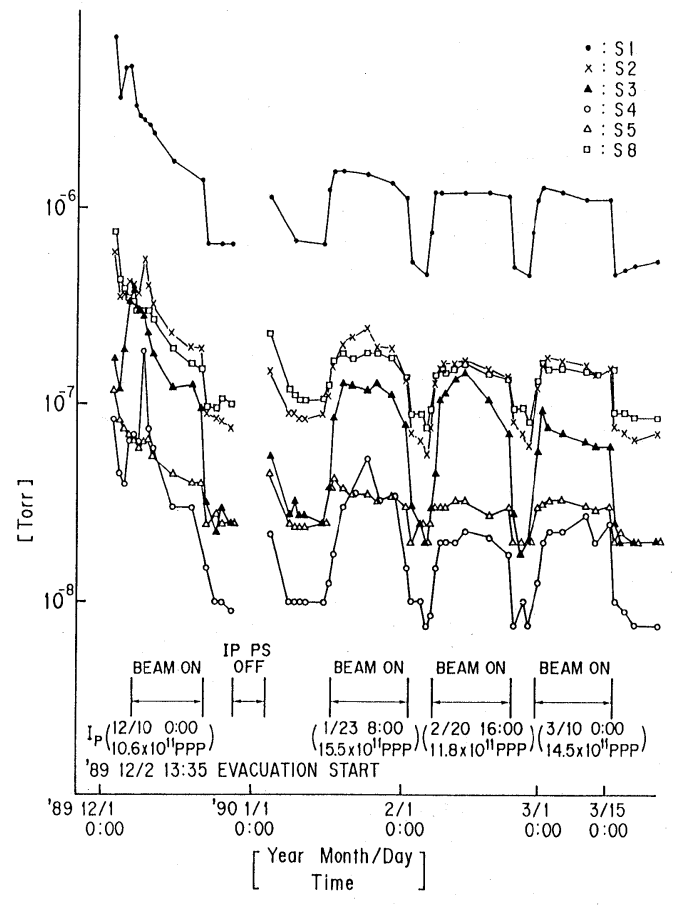

Fig. 4 The pressure distribution for a typical operation of KEK-PS Booster.

は真空の外に出す設計が必要となる。また $\mathrm{S}_{6}, \mathrm{~S}_{7}$ には NEG 等のスペースを取らないポンプを設置することも 有効であろら。

\section{5. ブースターリングの残留ガス分布の検討}

一般に加熱脱ガスをしない系で $10^{-6} \sim 10^{-7}$ Torr の平 衡圧力となる場合は， $\mathrm{H}_{2} \mathrm{O}$ が残留ガスの主な分圧を示 すことが通常である. しかしながらブースターリングで は上記の圧力領域で残留ガス成分を観察すると, イオン ポンプ $(1000 \mathrm{l} / \mathrm{s} \times 6$ 台）のみで排気している時は，水 素が主ピークとなり，またターボ分子ポンプ (300ll $\mathrm{s} \times 3$ 台）のみで排気した場合は水が主ピークとなる。

したがって排気するポンプの種類によってガス種が異な ることが観察された. ただし，イオンポンプとターボ分 子ポンプの排気速度が合計で， $6000 \mathrm{l} / \mathrm{s}$ と900 l/s と異な り，圧力がちがうために直接比較するには問題がある. そこでFig. 5 に示すような装置によってブースタ一圧 力の分圧特性のポンプによる変化について検証した.

Fig. 6 に示すように, やはり, ターボ分子ポンプのみで 排気している時は水が，イオンポンプのみで排気してい る時は水素が主ピークであった。一酸化炭素はイオンポ ンプを使用することによって増加している．以上のこと

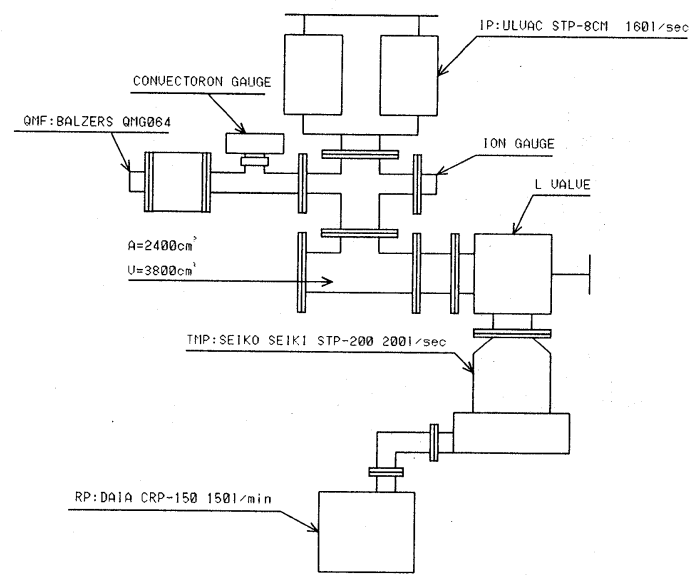

Fig. 5 Exprimental setup of IP and TMP system.

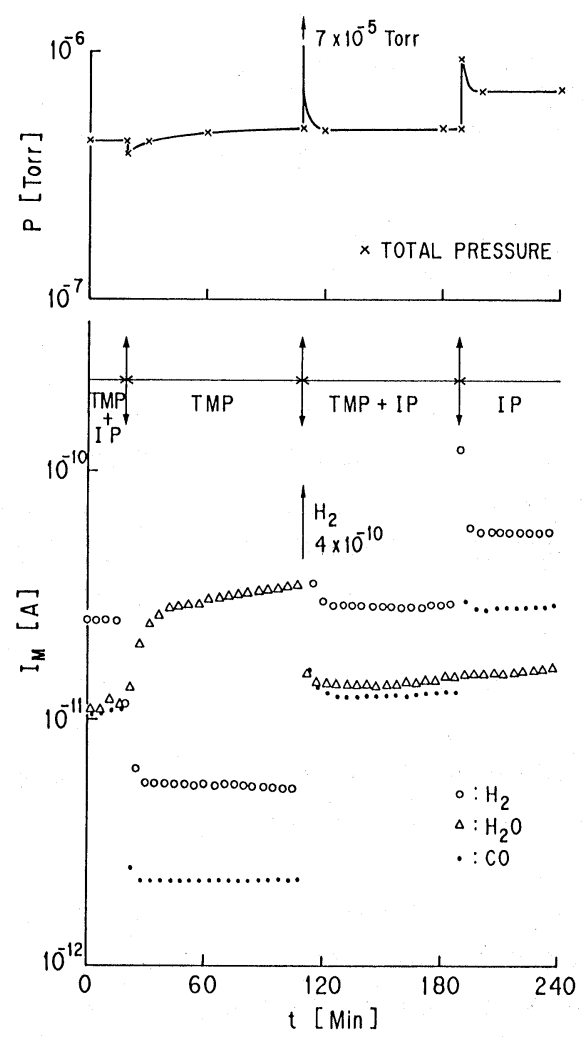

Fig. 6 Total and partial pressure variation of the residual gases in different pumping systems of IP and TMP.

は，加熱脱ガスをしない系での残留ガスの主成分は水で あり，これをイオンポンプのみで排気すると，放電空間 内で水が解離して水素と酸素となっていることを示して 
いる．酸素は活性なチタンを酸化させるので，ゲッター の性能が劣化し, 水素が残留ガスの主成分になることが 考兄られる. またイオンポンプ起動時の圧力が高いとこ の傾向はさらに強くなる．したがってセルフベーキング によるイオンポンプの起動はポンプの性能の劣化を進行 させると考兄られる。

\section{6. まと め}

(1) イオンポンプの起動方法に関する提案

ガス負荷の大きな真空系の立上時間を短くするために はイオンポンプの起動時の圧力を出来るだけ下げること が望ましい，しかし通常加速器では, イオンポンプの排 気口にバルブを取り付けないことが多く, 保守のたびに ポンプも一気圧に曝されて, 起動特性, 到達圧力に悪い 影響を与えている. 今回の試験から，イオンポンプのへ ッドにバルブを取り付けることによって起動時間は大幅 に短縮され良好な結果が得られることがわかった。この
ことは, 設計時の判断一つで, その後のマシンの性能を 決定する要因となることを示している.

\section{(2) 粗排気及び主排気に関する提案}

加熱脱ガスをしない系では, 粗排気だけでなく, 主排 気に颃いても水の排気が重要である.今回観察されたイ オンポンプ排気系での水の解離は, ポンプの性能を劣化 させると考えられる．したがってこの水に大きな排気速 度を持つ，たとえばクライオ面を使用して排気系の性能 を向上させることが考劣られる，以上述べてきたことは 当然の結果ではあるが，これらが現実のマシンの設計に 生かされていることが少ない、またイオンポンプは加熱 脱ガスをしないと正常な性能が得られないこと，さらに 一気圧に曝すたびに性能は劣化するものとして取扱い， 設計することが後々のために重要であるといえる.

\section{[文献]}

1）堀越源一：真空, 16 (1973) 51 